\title{
Academic integrity in first-year nursing students: An intergrative review
}

\author{
Kolleen Miller-Rosser*1, Jann Fielden ${ }^{2}$, Elizabeth Emmanuel ${ }^{2}$ \\ ${ }^{1}$ Faculty of Health, Southern Cross University, Coffs Harbour Campus, New South Wales, Australia \\ ${ }^{2}$ Faculty of Health, Southern Cross University, Gold Coast Campus, Queensland, Asutralia
}

Received: August 8, 2021

DOI: $10.5430 /$ jnep.v12n3p31
Accepted: October 19, 2021

Online Published: October 25, 2021

URL: https://doi.org/10.5430/jnep.v12n3p31

\begin{abstract}
Introduction: Studies relating specifically to first-year nursing students' breaches of academic integrity are not readily identified within the literature. While work has, over the years reported on breaches in academic integrity, it has done so with many disciplines and varied student cohorts. Nevertheless, those that specifically relate to first-year nursing students are sparse. First-year undergraduate nursing students are generally included with the entire student nurse cohort, and not necessarily identified independently. Therefore, the integrative review aimed to discover how or if the incidence of plagiarism/cheating, specifically within first-year undergraduate nursing students, was addressed.

Methods: An integrative review of the literature, incorporating quantitative and qualitative literature was undertaken between January 2021 - April 2021 using electronic data bases.

Results: Ten studies met the inclusion criteria. From the review, six main themes were extrapolated, (1) blurred boundaries of caring; (2) navigating the ethical highway; (3) factors influencing academic misconduct (4) early intervention (5) academic integrity policies and procedures and (6) inconsistencies amongst academics.

Conclusions: The integrative review has identified a shortfall in research relating to how academic integrity has been addressed in first-year nursing students.
\end{abstract}

Key Words: Academic integrity, Ethics, Plagiarism, Educational interventions, Nursing

\section{INTRODUCTION AND BACKGROUND}

While there is a plethora of research into students, in general, relating to aspects of academic integrity $(\mathrm{AI}),{ }^{[1]}$ there has been little focus on nursing students worldwide, and specifically first-years. This, we believe is a major concern. The focus on AI (AI) in first-year nursing students is imperative, as this year is considered the foundational period of a student's academic journey. Studies show that there is a distinct misalignment between faculties and students in how well prepared for academic writing they are, which potentially leads to student integrity transgressions within their educational journey. ${ }^{[2]}$ While Guerrero-Dib et al. identified that introducing first-year nursing students to the values and practices of AI facilitates student achievement of high standards of excellence and learning ${ }^{[3]}$ Emmanuel et al. further recognised that early focus on AI can lead to students developing good ethical perspectives. ${ }^{[4]}$

$\mathrm{AI}$ is an integral part of all university degrees. It is postulated that breaches in AI, in nursing, are increasing, especially with the increasing use of and reliance upon modern technology

\footnotetext{
* Correspondence: Kolleen Miller-Rosser; Email: kolleen.miller-rosser@ scu.edu.au; Address: Faculty of Health, Southern Cross University, Coffs Harbour Campus, Hogbin Drive, Coffs Harbour, NSW, 2450, Australia.
} 
in the academic arena. ${ }^{[4]}$ Breaches of AI can give students unwarranted advantage in their academic work. Types of breaches include but are not limited to: cheating, plagiarism (intentional or unintentional), recycling of previously submitted work, and collusion. ${ }^{[5]} \mathrm{AI}$ is a global issue impacting tertiary education, ${ }^{[6]}$ and nursing degrees are not immune. This is of major concern as integrity, authenticity, honesty and trustworthiness are fundamental qualities to the nursing profession and standards of practice. ${ }^{[7-9]}$ This moral compass is central during the educational process ${ }^{[3]}$ and begins in the first-year.

Following our investigation relating to why should academics care about $\mathrm{AI},{ }^{[4]}$ we attempted to uncover the extent to which practice in AI among first-year nursing students is occurring, through an integrative review of the literature.

\section{METHOD}

An integrative review was undertaken to identify the correlation between first-year undergraduate nursing students and incidences of breaches in AI. This review method involved synthesising the evidence-based knowledge to describe and explore how first-year nursing students were represented, in relation to breaches in AI. Based on this, the researchers used the five phases as identified by Whittemore and Knafl,, ${ }^{[10]}$ which encompassed problem identification, literature search, data evaluation, data analysis and presentation. These phases offered the researchers the opportunity to include primary evidence for collation, analysis, and synthesis. The findings described aspects of breaches in AI, specifically relating to first-year nursing students, and how they were reported. Main themes were then extrapolated. This constant comparative method across three reviewers allowed for identification of patterns and finally themes. ${ }^{[10,11]}$

\subsection{Literature search strategy}

A systematic search strategy, with the assistance of a Librarian, was undertaken between January - April, 2021. Five electronic databases were used in the search strategy. These data bases consisted of CINAHL, ERIC, Medline, ProQuest in nursing and Scopus. The search consisting of seven steps, was conducted using Mesh headings, abbreviations, and relevant terms. In each step, articles were limited to peer reviewed journals; English language and no limitation placed on date ranges. From the final list, references were searched for those articles not identified in the original search. All researchers independently reviewed the 48 full text articles to identify those for inclusion in the review.

\subsection{Search outcome}

A total of 48 articles with possible significance were identified, through the search criteria. A further 6 articles were selected through trawling the references of the identified papers, bringing the total to 54. A further 4 were excluded due to repetition. The final 50 papers were reviewed by the authors, based on the inclusion/exclusion criteria. From this scrutiny, 10 articles were deemed to meet the inclusion criteria, and included in the final analysis. The search outcome was formulated based on the PRISMA checklist and illustrated in the four phases flow chart as shown in Figure 1.

\subsection{Inclusion and exclusion criteria}

The inclusion criteria consisted of primary research articles that focused on first-year nursing students, plagiarism, cheating, dishonesty, and breaches of AI. Articles that incorporated first-years with other years, were reviewed to ascertain whether first-year information was specifically identified and if so, included. The articles that did not differentiate between first-years and nursing students from all other years were excluded. In addition, articles were excluded based on being case studies, reports relating to AI, or did not specifically relate to first-year nursing students.

\subsection{Data evaluation}

The Critical Appraisal Skills Programme (CASP) system of appraisal was adopted to appraise the studies for rigor, methods, credibility, and relevance. ${ }^{[13]}$ This system of appraisal is a tool well utilized by health professionals to ensure relevance, trustworthiness, and findings from research papers. All three reviewers critiqued the studies for design, methods and study details including aims, ethical considerations, sample population and size, interventions, and outcome measures.

\subsection{Extrapolation of the main themes}

Upon final agreement of the articles that met the criteria, each author, independently, reread the articles, and inputted their information onto a spreadsheet, which included headings such as key findings and 'themes that stood out'. Once finalised, each author sent the spread sheet back to the main author, who collated the information into one spread sheet for further analysis. All authors met and discussed what patterns if any, were emerging from the data. This was achieved by way of dividing 'like' data into subgroups, where an examination of relationships was identified and those with similar traits were clustered together, for further analysis. ${ }^{[10]}$ The process of the constant comparing ${ }^{[10]}$ was repeated until authors had completed the analysis. The final phase of this analysis, once the main themes had been identified, resulted in all authors agreeing on the themes, and identifying a heading that was congruent with identified themes. 


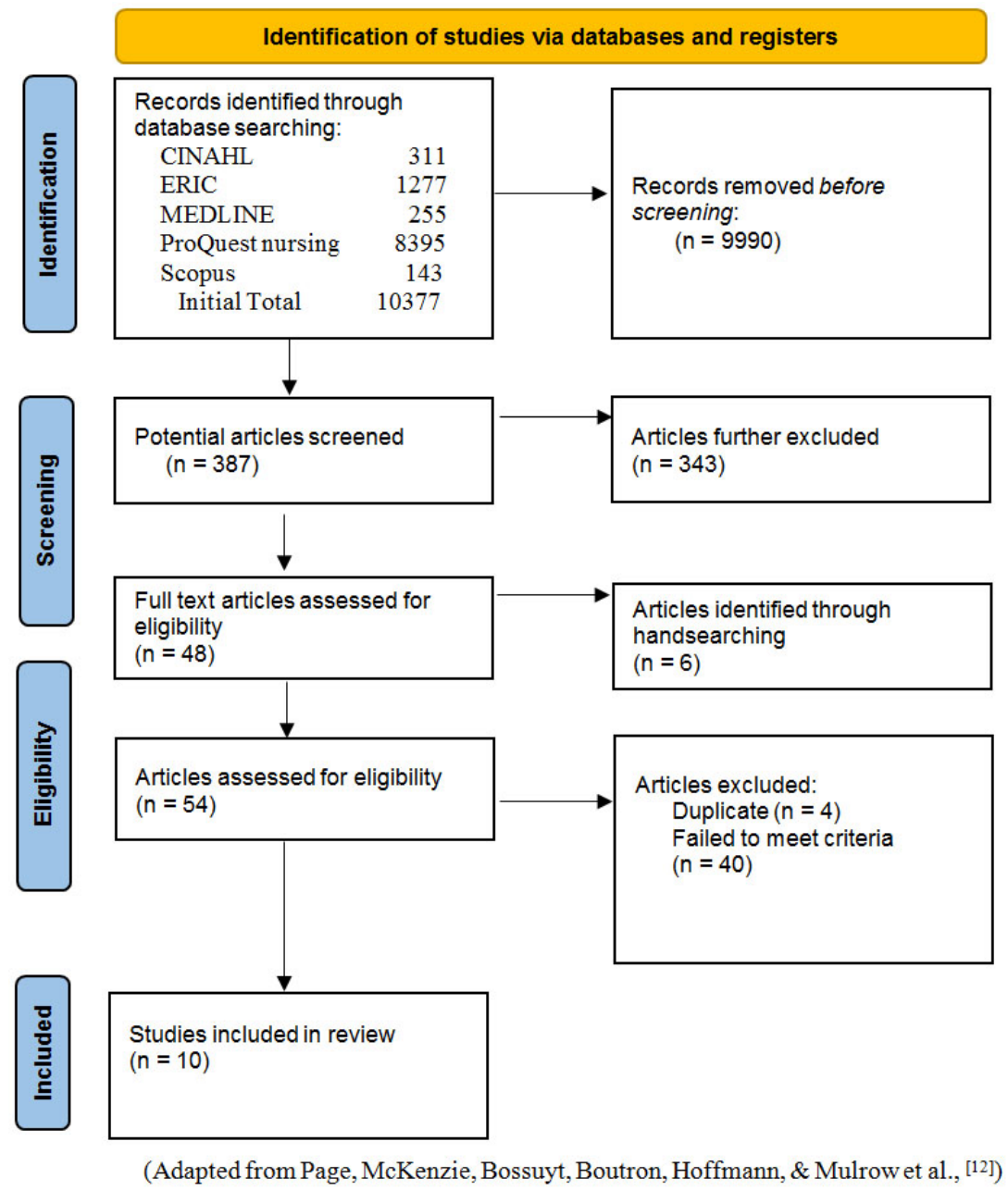

Figure 1. PRISMA Flow chart of studies included in the review

\section{RESULTS}

The 10 articles included in the review were published between 2002 and 2020. The studies were undertaken from Australia (3); South Korea (2); Canada (1); Norway (1); Turkey (1) and United States of America [USA] (2). The participants within the articles, were undergraduate nursing students undertaking a baccalaureate of nursing degree. Results reported here focus solely on the identified first-year nursing students within each of the studies. Study designs included cross-sectional descriptive studies, pre and post, open ended and questionnaire surveys, a self-developed questionnaire, and interviews. From this, six themes were identified: (1) blurred boundaries of caring; (2) navigating the ethical highway; (3) factors influencing academic misconduct (4) early intervention (5) AI policies and procedures and (6) inconsistencies amongst academics.

\subsection{Blurred boundaries of caring}

Nursing is a caring profession. However, this concept appears to be readily taken out of context in the studies reviewed. Students were reluctant to report colleagues for Published by Sciedu Press cheating because of the caring nature of nursing. ${ }^{[15,25]}$ Wide$\operatorname{man}^{[25]}$ found that students misinterpreted the caring aspect of nursing and how they are taught to be non-judgemental when caring for patients, as being acceptable in assisting fellow students who are struggling, even if that involved a degree of plagiarism, collusion or dishonesty, as such behaviour was seen as caring.

Neutralization behaviours were identified ${ }^{[14,21,25]}$ when justifying cheating. Students accept that cheating is prevalent among their colleagues, therefore considered as a way of life ${ }^{[15]}$ in this contemporary educational arena. A point so aptly identified when discussing the acceptability of cheating, students claimed "everybody does it", ${ }^{[15]}$ (p 6). Wideman ${ }^{[25]}$ postulated that neutralization was a way that students legitimized their dishonest behaviour. Here, the author further explained that being dishonest in academia was part of a students lived experience; at some point in their degree, they will either be part of it or be witness to it. Therefore, if students are not adversely impacted personally by others cheating, it is tolerated. ${ }^{[21]}$ 
Table 1. Summary of reviewed papers

\begin{tabular}{|c|c|c|c|c|}
\hline $\begin{array}{l}\text { Reference/ } \\
\text { Country }\end{array}$ & Participants & Study design & Key study finding & Strengths and limitations \\
\hline $\begin{array}{l}\text { Birks et al., }{ }^{[14]} \\
\text { Australia }\end{array}$ & $\begin{array}{l}\text { Undergraduate nurses } \\
(\mathrm{n}=361) \text {. } \\
26.6 \% \text { first-year nurses }\end{array}$ & $\begin{array}{l}\text { Cross-sectional } \\
\text { online survey. } \\
\text { Modified tool of } \\
\text { Windrow et al. } \\
\text { (2015) used. }\end{array}$ & $\begin{array}{l}\text { About half of participants reported being } \\
\text { involved in academic misconduct. However, } \\
\text { frequency of repeated misconduct was low. } \\
\text { A significant association shown between age and } \\
\text { misconduct though not specifically linked to } \\
\text { first-year }\end{array}$ & $\begin{array}{l}\text { Strengths: Amended survey tested for } \\
\text { face and content validity. } \\
\text { Limitations: Sample size limited to } 3 \\
\text { states, predominantly women and in } \\
\text { part-time employment. Focus not on } \\
\text { first-year }\end{array}$ \\
\hline $\begin{array}{l}\text { Brown }{ }^{[15]} \\
\text { US }\end{array}$ & $\begin{array}{l}18 \% \text { seniors, } 17 \% \\
\text { freshmen, } 27 \% \\
\text { sophomore, } 19 \% \text { junior, } \\
19 \% \text { senior } \\
\text { baccalaureate nursing } \\
\text { students. }\end{array}$ & $\begin{array}{l}\text { Survey questionnaire } \\
\text { with } 4 \text { closed } \\
\text { (Yes/No) questions, } \\
\text { \& } 3 \text { open ended } \\
\text { questions }\end{array}$ & $\begin{array}{l}\text { Themes from open ended question included using } \\
\text { cheat sheets, using other students' assessments. } \\
\text { Quantitative results included senior students who } \\
\text { thought about cheating, however only few } \\
\text { cheated }\end{array}$ & $\begin{array}{l}\text { Strengths: Survey questions clearly } \\
\text { identified. } \\
\text { Limitations: Brief report with limited } \\
\text { details that would allow adequate } \\
\text { critique. Focused primarily on senior } \\
\text { students. }\end{array}$ \\
\hline $\begin{array}{l}\text { Cho and Hwang }{ }^{[16]} \\
\text { South Korea }\end{array}$ & $\begin{array}{l}581 \text { undergraduate } \\
\text { nursing students across } \\
3 \text { universities } \\
23 \% \text { first years }\end{array}$ & $\begin{array}{l}\text { Cross-sectional, } \\
\text { survey. Adapted } \\
\text { Kwon et al.'s }{ }^{[17]} \\
\text { survey }\end{array}$ & $\begin{array}{l}\text { Male first-year students, those who were satisfied } \\
\text { with their degree programme and students } \\
\text { experiencing lower stress had greater ethical } \\
\text { awareness. Behaviours considered unethical } \\
\text { included: violating patient respect or } \\
\text { confidentiality; cheating on exams; dishonest } \\
\text { behaviour's during clinical practice. not } \\
\text { sanctioned by penalties were seen to be } \\
\text { acceptable. Ethical awareness higher in first-year } \\
\text { compared to others. }\end{array}$ & $\begin{array}{l}\text { Strengths: Content validity \& reliability } \\
\text { of tool tested. Presentation of details in } \\
\text { research reporting. } \\
\text { Limitations: Findings cannot be } \\
\text { generalised to other regions in S. Korea. } \\
\text { No qualitative component included }\end{array}$ \\
\hline $\begin{array}{l}\text { Kececi et al., }{ }^{[18]} \\
\text { Turkey }\end{array}$ & $\begin{array}{l}196 \text { nursing students } \\
\text { included } 43 \% \text { 1st years }\end{array}$ & $\begin{array}{l}\text { Cross sectional } \\
\text { survey. Included } \\
\text { Academic } \\
\text { Dishonesty } \\
\text { Tendency Scale by } \\
\text { Eminoglu \& Nartgun } \\
{[19]}\end{array}$ & $\begin{array}{l}\text { Male students had greater tendency towards } \\
\text { academic dishonesty } \\
\text { First-year tend more to copy references; students } \\
\text { from extended families more inclined towards } \\
\text { academic dishonesty; increased tendency for } \\
\text { academic dishonesty when the educator has } \\
\text { liberal attitudes about cheating. }\end{array}$ & $\begin{array}{l}\text { Strengths: Tool measured for validity } \\
\text { and reliability Limitations: Study } \\
\text { questions not clear; less than half of } \\
\text { students were first-year. Some } \\
\text { contradictions in data collection. } \\
\text { Limited generalisation. }\end{array}$ \\
\hline $\begin{array}{l}\text { Nierenberg }{ }^{[20]} \\
\text { Norway }\end{array}$ & $\begin{array}{l}418 \text { first-year nursing } \\
\text { students }\end{array}$ & $\begin{array}{l}\text { Pre- and } \\
\text { post-12-intervention } \\
\text { survey. } \\
\text { Self-designed tool }\end{array}$ & $\begin{array}{l}37 \% \text { nursing students self-reported in pre-test; } \\
22 \% \text { self-reported in post-test. their ability to } \\
\text { avoid plagiarism as good or very good (pre-test). } \\
\text { This increased to } 77 \% \text { in the post-test survey. } \\
\text { Nursing students were more confident in their } \\
\text { ability to evaluate sources. }\end{array}$ & $\begin{array}{l}\text { Strengths: Comparative nature of study. } \\
\text { Limitations: Validity and reliability of } \\
\text { tool not reported. Small sample size and } \\
\text { low response rate for nursing students. } \\
\text { Results not representative of the wider } \\
\text { nursing student population. }\end{array}$ \\
\hline $\begin{array}{l}\text { Park et al., }{ }^{[21]} \\
\text { South Korea }\end{array}$ & $\begin{array}{l}655 \text { undergraduate } \\
\text { nursing students } \\
\text { Encompassed all four } \\
\text { years of the degree } \\
\text { program } \\
\text { across } 4 \text { campuses } \\
20 \% \text { identified as } \\
\text { first-years }\end{array}$ & $\begin{array}{l}\text { Cross sectional } \\
\text { survey. Tool items } \\
\text { derived from } \\
\text { literature. }\end{array}$ & $\begin{array}{l}\mathrm{n}=44(32 \%) \text { of first-year admitted to plagiarism; } \\
\mathrm{n}=90(58 \%) \text { of first-years did not cheat. }\end{array}$ & $\begin{array}{l}\text { Strengths Content validity and reliability } \\
\text { sought. Excellent response rate. Use of } \\
\text { multi campuses. } \\
\text { Limitations: Cheating behaviours and } \\
\text { proportions vary at different time frames } \\
\text { during the program. }\end{array}$ \\
\hline $\begin{array}{l}\text { Pence }^{[22]} \\
\text { US }\end{array}$ & $\begin{array}{l}43 \text { enrolled in Allied } \\
\text { Health course; } 5 \% \\
\text { first-year nursing } \\
\text { students }\end{array}$ & $\begin{array}{l}\text { Descriptive, online } \\
\text { self-designed survey } \\
\text { based on literature } \\
\text { and previous } \\
\text { students' work }\end{array}$ & $\begin{array}{l}\text { Severe consequences for cheating, the way } \\
\text { examinations are }\end{array}$ & $\begin{array}{l}\text { Strengths: Content validity of tool } \\
\text { established. Good response rate } 42 / 43 \text {; } \\
\text { Had survey validated by educators and } \\
\text { first-year nurses } \\
\text { Limitations: Small sample size of } \\
\text { first-year nursing students. }\end{array}$ \\
\hline $\begin{array}{l}\text { Smedley et al., }{ }^{[23]} \\
\text { Australia }\end{array}$ & $\begin{array}{l}118 \text { first-year nursing } \\
\text { students completed } \\
\text { pre-survey; whilst } 70 \\
\text { complete the post } \\
\text { survey }\end{array}$ & $\begin{array}{l}\text { Pre and post } \\
\text { intervention survey. } \\
\text { Tool adapted from } \\
\text { Pence }{ }^{[22]} \text {. }\end{array}$ & $\begin{array}{l}\text { General improvement of knowledge and } \\
\text { understanding of plagiarism post intervention. } \\
\text { Significant improvement among 20-24-year-old } \\
\text { cohort }\end{array}$ & $\begin{array}{l}\text { Strengths: Acceptable reliability } \\
\text { achieved. Methods well explained. } \\
\text { Survey questions well established and } \\
\text { tested using Delphi process } \\
\text { Limitations: Study undertaken in a } \\
\text { private college; small cohort of nursing } \\
\text { students; limited response rate (59\%) } \\
\text { post survey }\end{array}$ \\
\hline $\begin{array}{l}\text { Smedley et al., }{ }^{[24]} \\
\text { Australia }\end{array}$ & $\begin{array}{l}70 \text { matched responses } \\
\text { of first-year nursing } \\
\text { students form a } 2015 \\
\text { survey }\end{array}$ & $\begin{array}{l}\text { Pre and post } \\
\text { intervention survey. } \\
\text { Tool designed by } \\
\text { Pence (2012) }\end{array}$ & $\begin{array}{l}\text { Interventional activities greatly improved } \\
\text { students understanding on aspects relating to } \\
\text { plagiarism. However, knowledge of paraphrasing } \\
\text { and referencing low }\end{array}$ & $\begin{array}{l}\text { Strengths: Study showed interventions } \\
\text { had an impact on student's knowledge } \\
\text { relating to plagiarism } \\
\text { Limitations: Small sample size }\end{array}$ \\
\hline $\begin{array}{l}\text { Wideman }{ }^{[25]} \\
\text { Canada }\end{array}$ & $\begin{array}{l}2 \text { first-year nursing } \\
\text { students }\end{array}$ & $\begin{array}{l}\text { Phenomenological } \\
\text { approach using semi } \\
\text { structured } \\
\text { interviews }\end{array}$ & $\begin{array}{l}\text { Academic misconduct not perceived as such but } \\
\text { as a measure of caring and sharing. Tendency to } \\
\text { cheat was a means of coping with workload }\end{array}$ & $\begin{array}{l}\text { Strengths: Adequate sample size for the } \\
\text { study design; good data analysis } \\
\text { Limitations: Poor representation of } \\
\text { first-years; Unable to determine the } \\
\text { first-year nursing students' experience. }\end{array}$ \\
\hline
\end{tabular}




\subsection{Navigating the ethical highway}

Nursing has been considered as one of the most ethical and trustworthy professions for decades, and as such, the public expects nurses have a high level of professional integrity. ${ }^{[25]}$ Alongside professional integrity, is ethics. The concept of ethics, in general, was recognized in various ways in several of the studies. Birks et al. ${ }^{[14]}$ identified it would be expected that nursing students be more aware of ethical issues, due to the nature of their chosen profession. Whereas Park et al. ${ }^{[21]}$ identified that cheating is considered to happen less often in nursing due to the ethical nature of the profession. However, the researchers further found as nursing students become more competitive in their grades, unethical behaviours begin to surface. Kececi et al. ${ }^{[18]}$ reported within this modern era, changes in ethical views have become a problem; that ethics are being disregarded in lieu of achieving goals. This sentiment was further reverberated in other studies ${ }^{[15,21,22]}$ where it was identified that there was concern that unethical behaviours will continue through to the clinical area after graduation. An example of this was acknowledged by Cho and Hwang, ${ }^{[16]}$ who identified that falsifying and forging patient records was reported as a potential consequence of violating academic ethics.

Nurse academics embed the notion of ethics, as a foundational component within nursing curricula. Indeed, the importance of ethics for nursing students was frequently identified, under the guise of honesty and dishonesty, through the articles. Wideman ${ }^{[25]}$ reported that even though students enter University degrees with a preconceived idea of honesty, Universities and nursing programs must explicitly work towards creating an ethical culture within students, through provision of instruction about ethics in their nursing degrees. Kececi et al. ${ }^{[18]}$ identified that courses in ethics are offered in educational programs so that nursing students can develop ethical comportment. Pence ${ }^{[22]}$ identified that values, as set out by the American Nurses Association Code of Ethics for Nurses, should be instilled early within nursing education. Cho and Hwang ${ }^{[16]}$ acknowledged that first-year nursing students are required to undertake instruction in nursing ethics.

First-year nursing students do not necessarily view unethical behaviours as being unprofessional or cheating; many see such unethical behaviours as being the 'norm'. ${ }^{[16]}$ Pence ${ }^{[22]}$ additionally found this sentiment in their study. Kececi et al. ${ }^{[18]}$ found that even though students are cognizant that cheating is unethical, they believe that it is socially acceptable. Whereas Brown ${ }^{[15]}$ found that students viewed cheating as not being a concern and would "do so if they could get away with it" (p 7).

Published by Sciedu Press

\subsection{Factors influencing academic misconduct}

A busy curriculum and high student workload can be very challenging among first-year students. ${ }^{[14,18,25]}$ Within the reviewed studies, several factors were identified as contributing to academic misconduct among first-year nursing students. These include academic stress and low satisfaction with grades; ${ }^{[16]}$ situational stress, heavy workload, inconsistencies amongst academics, ease of cheating provided through technology, curriculums that do not address AI directly; ${ }^{[25]}$ low socio-economic status, limited understanding about referencing; ${ }^{[18]}$ inconsistent penalties for proven breaches of AI by universities, being young and less mature; ${ }^{[14]}$ and past cheating behaviours, for example not getting caught. ${ }^{[21]}$

Birks et al. ${ }^{[14]}$ reports that younger students, although feeling threatened about being severely punished for cheating, are more likely to engage in cheating. Nevertheless, Kececi et al., ${ }^{[18]}$ report that first-year students appear to struggle with academic referencing issues, with increased breaches of unintentional AI. It was reported that at least $45.4 \%$ of students acknowledged engagement in academic misconduct in some way during their nursing studies, ${ }^{[14]}$ however, the proportion of this specifically related to first-years was not identified.

\subsection{Early intervention}

While plagiarism and academic cheating behaviours are not clearly understood amongst first-year nursing students, it has been identified that early education intervention appear to have effective results. ${ }^{[20,21,23]}$ The most outstanding results are from Smedley and colleagues ${ }^{[23,24]}$ who report an improvement in knowledge and understanding, particularly for the 20-24-year-old age group. Studies also suggest that educational intervention in the foundational year of nursing gave rise to increased familiarity of information and awareness of what is perceived as cheating at tertiary level, ${ }^{[21,23,24]}$ thereby postulating early interventions can help limit the escalation of academic misconduct.

To understand perspectives on cheating, Park et al. ${ }^{[21]}$ surveyed nursing students' perceptions on the importance of twelve interventions that might discourage cheating and found the least important intervention measures identified, were, lectures on AI and small sized classes. However, the primary importance was found to be increased supervision during examinations. Smedley et al. ${ }^{[23]}$ identified educational interventions which encompassed sessions on scholarly writing, infringements of $\mathrm{AI}$ and appropriate referencing. In this study, students were surveyed for their understanding and awareness of plagiarism pre and post the intervention. Results showed that educational interventions increased student's awareness of plagiarism. Smedley et al. ${ }^{[24]}$ extended their initial study results of 2015 and showed that 
although there was an increased understanding about plagiarism, students still struggled with paraphrasing. Nierenberg, ${ }^{[20]}$ showed similar results. Here, first-year nursing students completed a library information literacy course with the results showing a marked increase in confidence on how to reference and using literary sources, hence suggesting students were less likely to be plagiarising.

\subsection{AI policies and procedures}

Within nursing degrees, first-year students are encouraged to access university policies for information about AI. However, this is not consistent. Wideman (2011) reported that students did not know of university policies relating to $\mathrm{AI}$ and/or admitted to not accessing them after the first week of semester. This led to the question; do educators/tutors explain academic policies to their students? Birks et.al. ${ }^{[14]}$ identified the failure of academic programs adequately educating students on $\mathrm{AI}$, as being a factor that potentially increased the likelihood of dishonest behaviours. Wideman ${ }^{[25]}$ noted, academic staff spent limited time both expanding on the AI policy and explaining the implications. Spending time educating students in AI policies can enhance students' understanding of their ethical obligations. ${ }^{[16]}$

Contradictions between the academic policies and actual enacted penalties relating to academic breaches were found within this review. One such contradiction related to the appropriateness of a penalty to the type of AI breach. Cho and Hwang ${ }^{[16]}$ identified that in the event of violations in AI being uncovered, the penalties were relatively low, which lead to students exhibiting low ethical reasoning. A 'smack on the hand, don't do it again' approach appears to do nothing to deter students from breaching AI. A contradiction identified by Kececi et al. ${ }^{[18]}$ was that some universities appear to have policies and procedures in place, yet, students were not made aware of these, nor did they know where to find them. Similarly Park et al. ${ }^{[21]}$ identified that Universities needed to clearly identify to both students and staff, their policies relating to AI. Furthermore, Pence ${ }^{[22]}$ suggested a review of policies relating to academic dishonesty and plagiarism be undertaken by all educators.

\subsection{Inconsistencies amongst academics}

When a breach is identified, it has been argued the penalty could depend on the educator, rather than policy. Birks et al. ${ }^{[14]}$ identified that academics have faced increasing difficulties in ensuring that students do not breach the values of AI. Wideman ${ }^{[25]}$ concluded students reported inconsistencies among faculty members when it came to academic dishonesty; finding that one faculty member would never tolerate any form of plagiarism, however other faculty members would be more lenient.

Park et al. ${ }^{[21]}$ found one reason that nursing students cheated, related to variations in penalties from their professors or university. The authors further relayed that there needs to be a consensus into the handling of AI breaches; that Universities clearly communicate with faculty about their policies and procedures for managing breaches of AI, limiting ambiguity among educators and promoting fairness and consistency in penalties being applied.

An interesting finding from Nierenberg ${ }^{[20]}$ related to academic qualifications. She argued that as nursing has been viewed as being more practical than academic, it was difficult to attract educators with advanced degrees, therefore postulating their understanding of AI may be less. The author further supported her argument, by identifying, when it comes to aspects of AI, some teachers lack the knowledge on what is required. Hence, it can be assumed, that some instances of AI breaches go undetected, and the learning opportunity for students is missed.

\section{Discussion}

International literature focusing on first-year nursing students, relating to breaches in AI, were few. Those that were identified, mainly originated from Australia (x3), South Korea (x2), United States (x2), and with one study each from Canada, Norway and Turkey (see Table 1). This integrative review synthesised the evidence relating to first-year nursing students and confirms that globally, nurse researchers frequently mix all nursing students into one entity when exploring issues of AI. Therefore, the review has acknowledged there is limited information, specifically about first-year nursing students' knowledge relating to $\mathrm{AI}$ and its principles.

Most importantly the review, has identified that foundational AI aspects of first-year nursing programs is generally overlooked, and that valuable direction for vulnerable students, is remiss. Congruent with previous studies on first-year university students such as Mehar Singh and Ganapathy ${ }^{[26]}$ this review found that first-year students remained unclear about what constitutes academic misconduct. It would seem that nursing programs do not maximise opportunities to integrate the notion of AI into first-year subjects. Understandably, amidst a busy curriculum, emphasis on increasing students' awareness and understanding on how to avoid AI breaches, and taking personal responsibility fall along the wayside. This unintended consequence can leave students in situations where 'they don't know what they don't know', about AI.

The tendency to overlook first-year nursing students and their involvement in AI breaches, as shown in the review, is concerning. This oversight is confirmed by Sheeba Rani et

ISSN 1925-4040 E-ISSN 1925-4059 
al.'s ${ }^{[27]}$ study. Generally, enrolments in nursing programs are highest in the first-year compared to second and third years. When included, there is generally an imbalance in first-year representation and therefore their perspective appears toned down. For instance, in a national survey by Birks et al., ${ }^{[14]}$ a quarter of participants $(26.6 \%)$ were first-year, whilst Park et al. ${ }^{[21]}$ identified $20 \%$. The same approach is taken with the nursing curricula and the embedding of AI into a 'one size fits all' approach. This discounts consideration for common characteristics of first-years who can be identified as a diverse group with different language backgrounds, experiences, younger age group ${ }^{[28]}$ who are experiencing a steep learning transition.

Nursing has been described as a caring and nurturing profession, both in this review and the existent literature. ${ }^{[6,8,29]}$ However, the concept of caring, within the review, could be construed as misguided caring. Under the guise of caring, it was identified in the review that first-year nursing students thought they should nurture their colleagues and that sharing their academic work with student colleagues, showed that they care about their peers. Conversely, studies also show, in general, that nursing students are less tolerant of dishonest behaviour. $^{[8]}$ Additionally, studies revealed that some nursing students actually reported cheating. This demonstrates the foundational concept of integrity are being acknowledged in the classrooms and clinical settings even during challenging times. ${ }^{[30]}$ In turn facilitating development of academic integrity prepares students to provide quality and safe care for patients based within ethics. ${ }^{[31]}$

Breaches in AI, in any form, is considered unethical, and has been discussed over the decades by various authors. ${ }^{[6,9,24]}$ However, AI breaches remain an ethical dilemma for both nursing students and academics. While the consequences of breaching AI are wide and varied, one such alarming consequence, is the potential continuation of this dishonest practice into the clinical environment. Allen et al. ${ }^{[32]}$ reported that there was a real threat of unethical academic dishonesty being transferred into the nursing environment, and as such a zero tolerance of breaches in AI while students are studying must have a clear message attached. Baxter and Boblin ${ }^{[33]}$ identified that unethical behaviour in the academic and clinical setting, is not only of grave concern for educators, but also for clinical educators, as there is a potential to carry this behaviour over into patient care. Eby et al. ${ }^{[34]}$ concur and argue it is not acceptable to fail to address matters of academic dishonesty because of the potential deleterious effects it may have on patient care. From these findings, dishonest academic behaviours may transfer into dishonest nursing practices upon graduation. Therefore, as educators of the next generation of nurses, it is vital that all academics

Published by Sciedu Press provide instruction to, and become aware of, their students understanding of professional morals and ethical behaviours.

Carter et al. ${ }^{[9]}$ argue that a cultural shift in ethical reasoning may be reflected in today's society and that increased political corruption and corporate fraud, can desensitize people, hence leading to acceptance of such behaviours, as seen in the universities around AI. However, because of the caring nature of nursing, one could argue that this desensitization should not find its way into the nursing profession. GuerreroDib et al. ${ }^{[3]}$ describes the development of the moral compass as something that should start in the home, presumably by parents/caregivers. Lynch et al. ${ }^{[29]}$ however, argues that the purported moral compass that gravitates students into the nursing profession, should not protect them from participating in academic dishonesty.

Factors leading into academic dishonesty for students has been identified in this review, and readily supported by the literature. ${ }^{[35,36]}$ A pertinent factor, identified by students, and raised in the literature is the pressure to succeed, ${ }^{[7,8]}$ which not only comes from family, but has been identified as coming from nursing educators. As educators, are we placing too much pressure on students to gain high grades? Are we inadvertently being party to the dishonesty cycle, through our expectations of students? Woith et al. ${ }^{[7]}$ answers this question, and found that as gatekeepers of the profession, nurse educators emphasize excellence in student performance. Tippitt et al. ${ }^{[37]}$ also suggested the nurse educator as the gate keeper to the nursing profession, is placing too greater emphasis on excellence of student performance.

Although this review covers few articles relating to firstyear nursing students, it is clear that academic misconduct poses a concern both for students and academic staff. This may be attributed to inconsistencies around how AI is promoted, enforced and dealt with. ${ }^{[14,20,25]}$ As Birks et al. ${ }^{[6]}$ suggests, academic misconduct is in reality a growing and systemic problem impacting on many universities and involves not only students, but academics and administrators. Carter et al. ${ }^{[9]}$ also identified the complexities of dealing with academic dishonesty, amongst academics. They found that while many educational institutions had in place policies on AI, educators varied in their methods of managing and consistently applying recommended interventions/penalties for academic breaches. Hence students may remain either confused about AI, or learn how to play off the 'softer' educators against those who apply educational intervention or enforce penalties.

Bultas et al. ${ }^{[8]}$ view the onus of AI as the responsibility of the educator. However, Emmanuel et al. ${ }^{[4]}$ found that academics have been found wanting in areas of AI, relating to the pres- 
sure felt when student evaluations are scrutinized. Hence more leniency may be shown when it comes to breaches in AI. Additionally, it could be argued that some academics may be 'time-poor' and do not report breaches due to the time involved to report/manage AI breaches or the lack of support provided. The authors support further research to uncover what these inconsistencies amongst educators are.

Implementing adequate and consistent policies and procedures in universities and curricula, is imperative when tackling the issues relating to AI. Birks et al. ${ }^{[6]}$ highlight the need for an unswerving approach to policies and procedure, educational processes for both academics and students. While it is evident that first-year nursing students are motivated and keen to achieve their goals, academic staff and administrators also need to assist students in developing a culture of AI, learning how to attend to their academic obligations and the resultant rewards, and avoid AI breaches. ${ }^{[3]}$

Universities generally, have standards, policies and procedures when it comes to AI, however the review uncovered conflicting information relating to policies and procedures. This raises the question; how then can students be expected to follow policies if they are not clearly identifiable? While it can be argued that processes for managing breaches in AI are embedded in University policies, it could be further argued this is not the case with all universities. ${ }^{[6]}$ It is important for all educational institutions to demonstrate a commitment in assisting students navigate the intricacies of AI, and to build that culture of AI in all students. ${ }^{[3]}$ Souza ${ }^{[38]}$ argued that most educational institutions have well established policies in place, however the educator and student have various interpretations of these policies.

Where it is easy to lay blame of policies and procedures at the door of the Universities, students also must take responsibility. They must immerse themselves in the policies to ensure that they are above reproach. Yet, as identified in this review, students do not always avail themselves or become cognizant of what AI is about. Additionally, within the literature, it was identified that students may not respect the rules relating to plagiarism by not adhering to them or not reading them. ${ }^{[38]}$

Educational interventions in the first-year have been shown to provide students with greater clarity regarding AI. ${ }^{[21,23]}$ As demonstrated by Nierenberg ${ }^{[20]}$ and Smedley et al., ${ }^{[24]}$ when knowledge is conveyed effectively and engagingly, correct interpretation of AI can prevent serious consequences. Therefore, it is prudent that appropriate educational interventions on academic writing (which entail the do's and don'ts), help students feel more confident in avoiding breaches. Bretag et al. ${ }^{[39]}$ reported students require guidance, support and learning about AI to develop skills that reflect the authenticity of their own work. Rather than having students make sense of what constitutes AI from the volume of written resources, a collective effort between the university and teaching staff is needed. Smedley et al. ${ }^{[23,24]}$ identified educational sessions, such as academic writing, appropriate referencing and how to avoid breaches, were shown to improve students' understanding and awareness.

\section{CONCLUSION/RECOMMENDATIONS}

To conclude, breaches in AI among first-year nursing students is a serious issue, worldwide. However, the responsibilities related to understanding and applying the values of $\mathrm{AI}$ are three-fold: students, academics, and Universities must continue to work together when looking at ways forward in addressing issues relating to AI, to bring that sense of trustworthiness and confidence back into the nursing profession. Breaches in AI throughout the literature have found this is an ongoing problem, not just for nursing but for many disciplines. Recommendations include:

- Further studies using various research designs incorporating larger sample sizes of first-year student nurses, relating to views/attitudes around AI.

- Studies involving University academics to ascertain their understanding and implementation of AI principles:

- Do they understand the Universities policies relating to breaches of AI?

- Do they report students for breaches of AI? If not, why?

- Exploration of alternative interventions with first-year nursing students relating to exams / essays and quizzes, face to face or online, to decrease the incidences of AI breaches.

- Orientation to and support for casual staff about polices relating to AI for consistency, when providing feedback on written assessments, and referrals of AI breaches.

- Consistent and nonpunitive (educational) approaches to penalties, so as students have the opportunity to show elements of $\mathrm{AI}$ and authenticity in their writing.

\section{Limitations}

The interpretations of the findings could be distorted by the various research methods used within the articles identified in this integrative review. Likewise, this point may be considered mute, as the various methodologies could be viewed as enhancing the findings, through increasing the richness and quality of data presented. For those studies identified where the researcher has carried out focus groups or interviews within their own academic setting, researcher bias could be 
present. In the studies where the participants are mainly female and/or male, this could be perceived as gender bias. While the researchers have maintained the highest level of rigour when undertaking this review, it is possible that some unpublished literature could have been missed.

\section{CONFLicts OF INTEREST Disclosure}

The authors declare that they have no competing interests.

\section{REFERENCES}

[1] Bretag T. Challenges in Addressing Plagiarism in Education. PLoS Med. 2013.

[2] Miron J, et al. Academic Integrity Education Across the Canadian Higher Education Landscape. Journal of Academic Ethics. 2021.

[3] Guerrero-Dib JG, Portales L, Heredia-Escorza Y. Impact of academic integrity on workplace ethical behaviour. International Journal for Educational Integrity. 2020; 16(1): 2. https ://doi.org/10.100 7/s40979-020-0051-3

[4] Emmanuel E, Fielden J, Miller-Rosser K. Why should we care about academic integrity in nursing students? Journal of Nursing Education and Practice. 2021. 11(5): 46-53. https ://doi .org/10.5430/jn ep.v11n5p46

[5] International Network for Quality Assurance Agencies in Higher Education (INQAAHE), Toolkit to support quality assurance agencies to address academic integrity and contract cheating. Government of Australia. 2020.

[6] Birks M, et al. Managing the mutations: academic misconduct in Australia, New Zealand and the UK. International Journal for Educational Integrity. $2020 ; 16(1): 6$. https ://doi .org/10.1007/s4 0979-020-00055-5

[7] Woith W, Jenkins S, Kerber C. Perceptions of academic integrity among nursing students. Nurs Forum. 2012; 47(4): 253-9. PMid:23127239 https://doi .org/10.1111/j.1744-6198. 20 $12.00274 . x$

[8] Bultas MW, et al. Crossing the "line": College students and academic integrity in nursing. Nurse Education Today. 2017; 56: 57-62. PMid:28668551 https://doi.org/10.1016/j.nedt.2017.06 .012

[9] Carter H, Hussey J, Forehand JW. Plagiarism in nursing education and the ethical implications in practice. Heliyon. 2019; 5(3): e01350. PMid:30949602 https://doi.org/10.1016/j.heliyon. 2019 .e01350

[10] Whittemore R, Knafl K. The integrative review: updated methodology. Journal of Advanced Nursing. 2005; 52(5): 546-553. PMid:16268861 https://doi.org/10.1111/j.1365-2648.20 $05.03621 . \mathrm{x}$

[11] Toronto C, Remington R, eds. A Step-by-step Guide to Conducting an Integrative Review. ed. C. Toronto, Remington, R. Springer Nature: Switzerland. 2020.

[12] Page MJ, et al. The PRISMA 2020 statement: an updated guideline for reporting systematic reviews. BMJ. 2021; 372: $n 71$.

[13] CASP, CASP Systematic Review Checklist. 2018.

[14] Birks M, et al. Exploring the paradox: A cros sectional study of academic dishonesty among Australian nursing students. Nurse Education Today. 2018; 65: 96-101. PMid:29547814 https://doi or $\mathrm{g} / 10.1016 / \mathrm{j}$. nedt .2018 .02 .040

[15] Brown DL. Cheating must be okay-everybody does it! Nurse Educator. 2002; 27(1): 6-8. PMid:11840063 https://doi.org/10.109 7/00006223-200201000-00010

[16] Cho OH, Hwang KH. Academic ethical awareness among undergraduate nursing students. Nursing Ethics. 2017; 26(3): 833-844.
PMid:28893158 https://doi.org/10.1177/09697330177271 55

[17] Kwon H, Lee YM, Lee YH. Development of an inventory assessing medical students' attitudes towards academic misconduct. Korean J Med Educ. 2013; 25(3): 211-20. PMid:25804850 https: //doi.org/10.3946/kjme.2013.25.3.211

[18] Keçeci A et al. Academic dishonesty among nursing students: a descriptive study. Nurs Ethics. 2011; 18(5): 725-33. PMid:21646326 https://doi.org/10.1177/0969733011408042

[19] Eminoğlu E, Nartgün Z. A scale development study to measure academic dishonesty tendency of university students. Journal of Human Sciences. 2009; 6(1): 215-240.

[20] Nierenberg E. A Comparison of Nursing and Teacher Education Students' Information Literacy Learning: Results from Norway, 2016 College \& Research Librarie. 2017; 78(5). https://doi.org/10.5860/crl.78.5.628

[21] Park EJ, Park S, Jang IS. Academic cheating among nursing students Nurse Education Today. 2013. 33(4): p. 346-352. PMid:23357719 https://doi.org/10.1016/j.nedt.2012.12.015

[22] Pence P. Plagiarism: using a collaborative approach in an online allied health professions course. Nurse Educ. 2012; 37(1): 12-6. PMid:22157995 https://doi.org/10.1097/NNE.0b013e3182 383701

[23] Smedley A, Crawford T, Cloete L. An intervention aimed at reducing plagiarism in undergraduate nursing students. Nurse Educ Pract. 2015; 15(3): 168-73. PMid:25578380 https://doi.org/10.101 $6 / j \cdot$ nepr.2014.12.003

[24] Smedley A, Crawford T, Cloete L. An Evaluation of an Extended Intervention to Reduce Plagiarism in Bachelor of Nursing Students. Nurs Educ Perspect. 2020; 41(2): 106-108. PMid:31107816 https://doi.org/10.1097/01.NEP.0000000000000492

[25] Wideman M. Caring or Collusion? Academic Dishonesty in a School of Nursing. Canadian Journal of Higher Education. 2011; 41: 22-43.

[26] Mehar Singh MK, Ganapathy M. Understanding Plagiarism from the Lens of First Year Tertiary Level Students. Pertanika Journal of Social Science and Humanities. 2018; 26: 159-178.

[27] Sheeba R, et al. Nursing students' perception and practices related to academic integrity. International Journal of Nursing Education. 2019; 11(2): 51-56. https://doi.org/10.5958/0974-9357.2019.0 0063.1

[28] Hector-Alexander A. Inclusive Curriculum Design, in Technology and the Curriculum, Summer 2019, A. Hector-Alexander, Editor. 2019, Pressbooks: Ontario Tech University.

[29] Lynch J, et al. Plagiarism in nursing education: an integrative review. Journal of Clinical Nursing. 2017; 26(19-20): 2845-2864. PMid:27808468 https://doi .org/10.1111/jocn. 13629

[30] Palmer J, et al. Nursing Examinations: Promotion of Integrity and Prevention of Cheating. Nurse Educ. 2016; 41(4): 180-4. PMid:26771943 https://doi.org/10.1097/NNE. 0000000000 000238

Published by Sciedu Press 
[31] Devine C, Chin E. Integrity in nursing students: A concept analysis. Nurse Educ Today, 2018. 60: p. 133-138. PMid:29112897 https://doi.org/10.1016/j.nedt.2017.10.005

[32] Allen J, Nichols C. Do you hear me? Student voice, academic success and retention. Student Success. 2017; 8(2): 123-129. https : //doi.org/10.5204/ssj.v8i2.387

[33] Baxter P, Boblin S. The moral development of baccalaureate nursing students: understanding unethical behavior in classroom and clinical settings. J Nurs Educ. 2007; 46(1): 20-7. PMid:17302096 https://doi.org/10.3928/01484834-20070101-05

[34] Eby R, et al. Fostering Ethical Integrity in Nursing Education. J Christ Nurs. 2017; 34(4): 250-255. PMid:28257304 https://doi org/10.1097/CN J.0000000000000390

[35] Bretag T, Handbook of Academic Integrity. 2016, Singapore:: Springer.
[36] Bailey P, et al. Assessing the impact of a study skills programme on the academic development of nursing diploma students at Northumbria University, UK. Health Information \& Libraries Journal. 2007; 24(s1): 77-85. PMid:18005297 https://doi.org/10.1111/j. $1471-1842.2007 .00741 . \mathrm{x}$

[37] Tippitt M, et al. Creating environments that foster academic integrity. Nurs Educ Perspect. 2009; 30(4): 239-44.

[38] Souza J. The plagiarism problem-reflections on plagiarism and nursing students, in Health Libraries group Nursing Bulletin. 2016; 18-23.

[39] Bretag T, et al. 'Teach us how to do it properly!' An Australian academic integrity student survey. Studies in Higher Education. 2014; 39(7): 1150-1169. https://doi.org/10.1080/03075079.201 3.777406 